\title{
Rheological and structural characterization of gels from whey protein hydrolysates/locust bean gum mixed systems
}

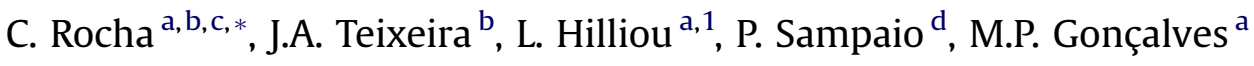 \\ ${ }^{a}$ REQUIMTE, Departamento de Engenharia Química, Faculdade de Engenharia, Universidade do Porto, Rua Dr. Roberto Frias, 4200-465 Porto, Portugal \\ ${ }^{\mathrm{b}}$ IBB - Institute for Biotechnology and Bioengineering, Centre of Biological Engineering, University of Minho, Campus de Gualtar, 4710-057 Braga, Portugal \\ ${ }^{\mathrm{C}}$ Escola Superior de Tecnologia e Gestão, Instituto Politécnico de Viana do Castelo, Apartado 574, 4900-348 Viana do Castelo, Portugal \\ ${ }^{\mathrm{d}}$ Advanced Light Microscopy Facility, IBMC - Instituto de Biologia Molecular e Celular, Universidade do Porto, Rua Campo Alegre 823, 4150-180 Porto, Portugal
}

\section{A R T I C L E I N F O}

\section{Article history:}

Received 29 July 2008

Accepted 11 February 2009

\section{Keywords:}

Whey protein hydrolysates

Locust bean gum

Gelation

Rheology

Microstructure

\begin{abstract}
A B S T R A C T
The gelling ability of whey proteins can be changed by limited hydrolysis and by the addition of other components such as polysaccharides. In this work the effect of the concentration of locust bean gum (LBG) on the heat-set gelation of aqueous whey protein hydrolysates $(10 \% \mathrm{w} / \mathrm{w})$ from pepsin and trypsin was assessed at $\mathrm{pH}$ 7.0. Whey protein concentrate (WPC) mild hydrolysis (up to $2.5 \%$ in the case of pepsin and $1.0 \%$ in the case of trypsin) ameliorates the gelling ability. The WPC synergism with LBG is affected by the protein hydrolysis. For a WPC concentration of $10 \%(\mathrm{w} / \mathrm{w})$, no maximum value was found in the $G^{\prime}$ dependence on LBG content in the case of the hydrolysates, unlike the intact WPC. However, for higher protein concentrations, the behaviour of gels from whey proteins or whey protein hydrolysates towards the presence of LBG becomes very similar. In this case, a small amount of LBG in the presence of salt leads to a big enhancement in the gel strength. Further increases in the LBG concentration led to a decrease in the gel strength.
\end{abstract}

(c) 2009 Elsevier Ltd. All rights reserved.

\section{Introduction}

Limited proteolysis can improve the functional properties of proteins by changing the molecular size, conformation, and strength of the inter- and intramolecular bonds of the protein molecules (Guan, Yao, Chen, Shan, \& Zhang, 2007).

Intrinsic (e.g. hydrophobicity, amino acid composition, molecular weight) or extrinsic factors (protein concentration, $\mathrm{pH}$, temperature, ionic strength, type of salts present, pressure, etc.) can affect the gel forming ability of a protein and the type of gel that will form, by changing the balance between attractive and repulsive reversible "physical" and/or irreversible (covalent) interactions (Dickinson, 1997; Totosaus, Montejano, Salazar, \& Guerrero, 2002). Hydrolysis of proteins may alter some intrinsic factors influencing thus the gelling properties of the "native" protein. For instance, hydrophobic interactions can play a major role in the gelation of several proteins and limited treatment with proteases leads to

\footnotetext{
* Corresponding author at: Escola Superior de Tecnologia e Gestão, Instituto Politécnico de Viana do Castelo, Apartado 574, 4900-348 Viana do Castelo, Portugal. Tel.: +351253 604400; fax: +351253678986.

E-mail address: crocha@deb.uminho.pt (C. Rocha).

1 Present address: I3N-Institute for Nanostructures, Nanomodelling and Nanofabrication, University of Minho, Campus de Azurem, 4800-058 Guimarães, Portugal.
}

some protein hydrolysis and consequently partial unfolding of the protein structure (Pinterits \& Arntfield, 2007). Unfolding of the native protein exposes buried hydrophobic groups and other interactive groups, which are then free to interact with neighboring polypeptides (Kang et al., 1994), thus promoting protein aggregation and subsequent gel setting.

The effect of hydrolysis on the gelation ability of whey protein is dependent on environmental conditions and on the degree of hydrolysis $(D H)$. In fact, extensive hydrolysis of WPI can impair its gelation properties (Huang, Catignani, \& Swaisgood, 1999). Therefore, the proteolysis reaction must be carefully monitored and controlled in order to manufacture products with desired functionality (Guan et al., 2007).

The type of enzyme chosen is also important and the specificity is different from one enzyme to another. Some enzymes can induce gelation following whey protein hydrolysis; others impair gelling properties (Doucet, Gauthier, \& Foegeding, 2001; Foegeding, Davis, Doucet, \& McGuffey, 2002; Otte, Lomholt, Ipsen, \& Qvist, 2000). For instance, although extensive enzymatic hydrolysis of whey proteins usually improves solubility and decreases gelling properties, non heat-set gelation occurs during extensive hydrolysis of whey protein isolate at high solid content $(20 \% \mathrm{w} / \mathrm{v})$ with Alcalase $2.4 \mathrm{~L}^{\circledR}$, a protease from Bacillus licheniformis (Doucet et al., 2001).

The functional properties of whey proteins (such as water solubility, water absorption, viscosity, gelation, emulsion 
properties, fat absorption, foaming properties, flavour and mineral binding abilities) can also be modified by the addition of other components. Proteins and polysaccharides are two important types of food macromolecules and are the most important structure forming ingredients in foods (Tolstoguzov, 1992). In fact, proteinpolysaccharide complexes exhibit many functional properties able to provide new food texturization and stabilization methods (Schmitt, Sanchez, Desobry-Banon, \& Hardy, 1998).

Synergistic effects have been found between whey proteins and several polyssacharides such as galactomannans, xanthan, pectin or carrageenan (Baeza, Carp, Perez, \& Pilosof, 2002; Bertrand \& Turgeon, 2007; Capron, Nicolai, \& Durand, 1999; Croguennoc, Nicolai, Durand, \& Clark, 2001; Gonçalves, Torres, Andrade, Azero, \& Lefebvre, 2004; Ndi, Swanson, Barbosa-Canovas, \& Luedecke, 1996; Tavares \& da Silva, 2003; Turgeon \& Beaulieu, 2001 and many others). However, to the best of our knowledge, the effect of protein partial hydrolysis on the protein-polysaccharide interactions has not yet been documented.

Locust bean gum (LBG) is a galactomannan (non-gelling neutral polysaccharides found in the endosperm of Leguminosae) widely used in the food industry as a thickening agent (Pollard \& Fischer, 2006). It is also known as carob gum or carubin. It has a linear main chain of $(1 \rightarrow 4)$-linked $\beta$-D-mannopyranosyl residues partially substituted with single $\alpha$-D-galactopyranosyl residues grafted by $(1 \rightarrow 6)$-linkages to the main chain (McCleary, Clark, Dea, \& Rees, 1985). The mannose to galactose ratio is ca. 3.5-4. Usually at high to intermediate mannose to galactose ratios (low degree of substitution), as is the case of LBG, the galactomannan is only partially soluble in water, while at very high levels of substitution the polymers are fully soluble (Pollard \& Fischer, 2006).

In this work the effect of LBG on the gelation of aqueous whey protein hydrolysates (WPH) from trypsin and from pepsin was assessed at $\mathrm{pH}$ 7.0. Rheological studies were carried out with different LBG concentrations and confocal laser scanning microscopy was used to analyse gels' microstructure. Two whey protein hydrolysates from trypsin and three whey protein hydrolysates from pepsin with different degrees of hydrolysis are studied.

\section{Materials and methods}

All chemicals used were of analytical grade and supplied by Sigma Co (St. Louis, MO, USA). Trypsin from porcine pancreas with an activity of 11,000 BAEE units/mg (chymotrypsin $\leq 0.2 \%$ ) - one BAEE unit will produce a $\Delta \mathrm{A}_{253 \mathrm{~nm}}$ of 0.001 per min at $\mathrm{pH} 7.6$ at $25^{\circ} \mathrm{C}$ using BAEE as substrate; in a reaction volume of $3.2 \mathrm{~mL}$ and $1 \mathrm{~cm}$ light path - was obtained from Sigma Chemical Co. Pepsin from hog stomach with an activity of 2540 units/mg protein (one unit will produce a $\Delta \mathrm{A}_{280 \mathrm{~nm}}$ of 0.001 per min at $\mathrm{pH} 2.0$ at $37^{\circ} \mathrm{C}$, measured as TCA-soluble products using hemoglobin as substrate in a reaction final volume of $16 \mathrm{~mL}$ and $1 \mathrm{~cm}$ light path) was also obtained from Sigma Chemical Co.

A commercial whey protein concentrate (WPC) powder (Lacprodan 80, batch Q500246) kindly supplied by Arla Food Ingredients (Viby, Denmark) was used for the experiments. According to the suppliers, the WPC dry basis protein content was $82 \%$ (5.5\% moisture), the ash content was 3.5\% max., the lactose content was $7 \%$, and fat content was $8 \% \max$.

Locust bean gum (>75\% galactomannan content) was kindly supplied by Danisco Portugal (Faro, Portugal).

\subsection{Hydrolysis of WPC}

Solutions of WPC were prepared by suspending $25 \mathrm{~g}$ of WPC in $500 \mathrm{~mL}$ of distilled water. The resulting solutions were stirred for $1 \mathrm{~h}$, then heated to the hydrolysis temperature $\left(37^{\circ} \mathrm{C}\right)$ and adjusted to the desired $\mathrm{pH}$ (2.0 for peptic hydrolysis and 8.0 for tryptic hydrolysis) with $\mathrm{NaOH}(1.0 \mathrm{M})$ or $\mathrm{HCl}(1.0 \mathrm{M})$. Enzymatic degradations were performed with trypsin or with pepsin in a $0.5 \mathrm{~L}$ stirred, tank-type, batch reactor equipped with $\mathrm{pH}$ and temperature control. The $\mathrm{pH}$ was kept constant with $0.5 \mathrm{M} \mathrm{NaOH}$ or $\mathrm{HCl}$. The degree of hydrolysis $(\mathrm{DH})$ achieved (ratio between the amount of peptide bounds cleaved and the total amount of peptide bounds) was measured by the TNBS method (Adler-Nissen, 1979). Inactivation of the enzymes was made by rising $\mathrm{pH}$ to 8 , in the case of peptic hydrolysates, or lowering $\mathrm{pH}$ to 3 , in the case of tryptic hydrolysates.

The suspensions resulting from the hydrolysis were lyophilised for further analysis. As ions can strongly influence the behaviour of the partially denatured $\beta$ - $\mathrm{Lg}$ (as referred by several authors including McPhail \& Holt, 1999) peptic hydrolysates were dialysed with a $100 \mathrm{Da}$ molecular weight cut off (MWCO) membrane (Spectrum Spectra/Por Biotech, Irvine, USA) against distilled water during $24 \mathrm{~h}$ prior to lyophilization (the water was changed four times). As the amount of alkali added to the tryptic hydrolysate during the hydrolysis procedure was lower, no dialysis was performed in this case.

\subsection{Salt analysis}

As the hydrolysis step involved the addition of either sodium hydroxide or hydrochloric acid to control the $\mathrm{pH}$ and/or to stop the reaction, determining the amount of sodium and chloride ions was important in order to allow the standardization of the ionic strength of the samples in the heat-set gelling studies. Although a dialysis step was introduced to reduce the amount of salt in the resulting hydrolysates, a significant amount of $\mathrm{Na}^{+}$and $\mathrm{Cl}^{-}$was still present.

Sodium content was determined by flame photometry with a flame photometer (JENWAY PFP7) equipped with a sodium filter $(589 \mathrm{~nm})$. Calibration was made with standard solutions of sodium chloride containing $3.9-19.7 \mathrm{mg} / \mathrm{L}$ of $\mathrm{Na}^{+}(10-50 \mathrm{mg} / \mathrm{L} \mathrm{NaCl})$. All standards and samples were analysed in triplicate.

Chloride content was determined through ionic chromatography. A liquid chromatograph (Dionex DX-300) was used equipped with a conductivity suppressor (Anion Micromembrane Suppressor AMMS-II), a conductivity detector (Dionex CDM-II), a manual injector with a $25 \mu \mathrm{L}$ loop, an AG4A (10-32) precolumn with $4 \times 50 \mathrm{~mm}(\mathrm{id} \times \mathrm{L})$, and an Ionpac AS4A (10-32) column with $4 \times 250 \mathrm{~mm}$ (id $\times \mathrm{L}$ ), both from Dionex. The eluent was a solution of $1.8 \mathrm{mM} \mathrm{Na}_{2} \mathrm{CO}_{3}$ and $1.7 \mathrm{mM} \mathrm{NaHCO}$ and the suppressor regenerator was a solution of $50 \mathrm{mN} \mathrm{H}_{2} \mathrm{SO}_{4}$. Operational conditions used were: eluent flow rate of $1.5 \mathrm{~mL} / \mathrm{min}$; suppressor regenerator flow rate of $4 \mathrm{~mL} / \mathrm{min}$; background conductivity of $20.2 \mu \mathrm{S}$. A calibration curve was built with standard $\mathrm{NaCl}$ solutions ranging between 0.6 and $18.2 \mathrm{mg} / \mathrm{L}$ of $\mathrm{Cl}^{-}(1$ and $30 \mathrm{mg} / \mathrm{L}$ of $\mathrm{NaCl}$ ).

\subsection{Purification of the $L B G$}

Locust bean gum was purified by precipitation with isopropanol as described by da Silva and Gonçalves (1990). A LBG solution $(1.5 \% \mathrm{w} / \mathrm{w})$ was prepared by gradually adding the gum to strongly stirred distilled water. The dispersion was stirred during $1 \mathrm{~h}$ at room temperature and then heated at $80^{\circ} \mathrm{C}$ for $30 \mathrm{~min}$. After cooling, the solution was centrifuged at $35,000 \mathrm{~g}$ at $20^{\circ} \mathrm{C}$ to remove the insoluble material. The solubilized LBG was recovered from the solution by slowly pouring (drop by drop) into a two volume excess of isopropanol with gentle mixing. The white fibrous precipitate was collected by vacuum filtration and washed consecutively with isopropanol, acetone and diethyl ether. Purified LBG was then dried under vacuum for $24 \mathrm{~h}$ and ground to a fine powder. 


\section{4. $W P H / L B G$ solutions}

Purified LBG stock solutions were prepared by gradually adding the gum to strongly stirred distilled water $(1.3 \% \mathrm{w} / \mathrm{w})$. Sodium azide (5 ppm) was added to each solution in order to avoid bacterial growth. The dispersion was stirred during $1 \mathrm{~h}$ at room temperature and then heated at $80^{\circ} \mathrm{C}$ for $30 \mathrm{~min}$. After cooling, the solution was centrifuged at $35,000 \mathrm{~g}$ to remove the insoluble material. The final concentrations of LBG solutions were determined from their dry matter contents.

To prepare the mixed systems, the required amount of WPC or WPH was weighted into polypropylene tubes and distilled water was added to pre-solubilize the protein. Then the required amount of LBG stock solution (ca. $1.3 \% \mathrm{w} / \mathrm{w}$ ) was added. Sodium azide solution ( $2 \mathrm{wt} \%$ ) was added to a final concentration of $5 \mathrm{ppm}$ in order to prevent bacterial growth. $\mathrm{NaCl}(20 \% \mathrm{w} / \mathrm{w})$ was added to a final salt concentration of approximately $0.1 \mathrm{M}$ to ensure constant ionic strength and the final concentration of solids was adjusted by adding distilled water. The solution was then gently stirred for $1 \mathrm{~h}$, at room temperature. The $\mathrm{pH}$ was adjusted to 7.0 and the solution was stirred for $2 \mathrm{~h}$ more. The final systems had a concentration of LBG ranging from 0 to $0.8 \% \mathrm{w} / \mathrm{w}$.

\subsection{Rheological measurements}

Dynamic oscillatory shear tests were performed in a controlled stress rheometer AR2000 (TA Instruments, Delaware, USA) fitted with a parallel plate geometry ( $40 \mathrm{~mm}$ diameter, gap $800 \mu \mathrm{m})$. A Peltier system in the bottom plate provided fast and accurate temperature control. Once placed on the measuring device at $20^{\circ} \mathrm{C}$, the surface of the samples in contact with the ambient was covered with a thin layer of liquid paraffin prior to the start of the tests, in order to prevent evaporation.

Five hydrolysates were tested: two from trypsin, with a degree of hydrolysis of 1.0\% (T1.0) and 3.5\% (T3.5), and three from pepsin with a degree of hydrolysis of 1.5\% (P1.5), 2.5\% (P2.5) and 4.9\% (P4.9).

Each sample was equilibrated during $5 \mathrm{~min}$; this step was followed by a frequency sweep ("mechanical spectrum") from 10 to $0.1 \mathrm{~Hz}$ at a strain of $5 \%$ (the sample was still liquid at this stage). Then a temperature ramp from 20 to $80^{\circ} \mathrm{C}$ was applied, at a rate of $2{ }^{\circ} \mathrm{C} / \mathrm{min}$, after which the temperature was maintained at $80^{\circ} \mathrm{C}$ for $3 \mathrm{~h}$. At the end of this time sweep the sample was cooled back to $20^{\circ} \mathrm{C}$, at the same constant rate $\left(2{ }^{\circ} \mathrm{C} / \mathrm{min}\right)$. The mechanical properties of the resulting gel were monitored at $20^{\circ} \mathrm{C}$ for $1 \mathrm{~h}$. Another frequency sweep $(10-0.01 \mathrm{~Hz}$ ) was recorded at this temperature. A maximum shear strain of $0.5 \%$ was used to record the storage $\left(G^{\prime}\right)$ and loss $\left(G^{\prime \prime}\right)$ moduli during the temperature, time and frequency sweep experiments after the first frequency sweep. Temperature, strain and time sweeps were performed at $1 \mathrm{~Hz}$.

A strain sweep from 0.1 to $2 \%$ was then made to verify that the produced frequency sweep was conducted within the linear viscoelasticity region. This was also confirmed on-line by systematic checking that the stress response to the applied sinusoidal strain was still sinusoidal during the corresponding rheological tests.

Finally, in order to assess the gel resistance, a steady state flow curve was measured by ramping the imposed shear stress from 0.01 to $150 \mathrm{~Pa}$ in 20 steps of $60 \mathrm{~s}$, and defining the steady state as a maximum of $5 \%$ variation in the recorded strain within the last $10 \mathrm{~s}$ of the stress step. Two replicates of some experiments were used to estimate errors. The replicate LBG and hydrolysates' solutions were freshly prepared, but the hydrolysate used was from the same batch. Thus the estimated errors do not include the error from the hydrolysis process, as all the conditions for the experiments were re-created except the hydrolysis process.
As the samples with higher degree of hydrolysis (P4.9; T3.5) did not gel at $10 \%(\mathrm{w} / \mathrm{w})$, the rheology tests for these hydrolysates were made with the minimum concentration required for achieving a gel in the absence of LBG. The resulting gels with no LBG were quite weak, and no microscopy tests were made for these samples.

\subsection{Microscopy study of the mixed gels}

Mixed solutions were prepared as described before. Proteins were stained with Rhodamine B Isothiocyanate (RBITC) through covalent linking between RBITC groups and the amino groups of the protein molecules. The solutions were placed on a concave slip, covered with a slide and hermetically sealed to prevent evaporation. They were then placed in a water bath at $20^{\circ} \mathrm{C}$. A temperature ramp of $2{ }^{\circ} \mathrm{C} / \mathrm{min}$ was applied for $30 \mathrm{~min}$ followed by $3 \mathrm{~h}$ at $80^{\circ} \mathrm{C}$, after which the samples were allowed to cool to $20^{\circ} \mathrm{C}$ and stored in the absence of light. The microstructure of the samples was analysed $12 \mathrm{~h}$ after the cooling temperature ramp. The samples were observed with a $10 \times$ or $63 \times$ objective under a confocal laser scanning microscope (Leica TCS SP2 AOBS, Leica Ltd., Heidelberg, Germany) in the fluorescence mode, excited at $561 \mathrm{~nm}$ with a laser, and the emission fluorescence was recorded between $570 \mathrm{~nm}$ and $688 \mathrm{~nm}$. Images were analysed with the software Image J 1.38W (Rasband, W.S., ImageJ, U. S. National Institutes of Health, Bethesda, Maryland, USA, http://rsb.info.nih.gov/ij/, 1997-2007).

\section{Results and discussion}

\subsection{Mechanical properties}

The time evolution of the viscoelastic moduli and of the loss angle for mixed systems' hydrolysates/LBG followed the general behaviour reported for many biopolymer heat-set gelation processes including whey proteins gelation (see for instance Gonçalves, Sittikijyothin, da Silva, \& Lefebvre, 2004; Gosal \& RossMurphy, 2000; Hines \& Foegeding, 1993; Huang, Catignani, Foegeding, \& Swaisgood, 1994; Kavanagh, Clark, Gosal, \& Ross-Murphy, 2000; Lefebvre, Renard, \& Sanchez-Gimeno, 1998; Paulsson, Dejmek, \& Vanvliet, 1990; Tavares \& da Silva, 2003). An example for such time kinetics is presented in Fig. 1. At low temperatures $G^{\prime \prime}$ is initially slightly higher than $G^{\prime}$ because of the liquid nature of the sample (Kavanagh, Clark, \& Ross-Murphy, 2000). The values at this stage are quite scattered as they are very close to the resolution limit of the rheometer. As the temperature rises both moduli decrease until the gelation threshold is achieved (either before the end of the temperature ramp or during the time sweep step). As this point approaches, a sudden increase in the values of $G^{\prime}$ and $G^{\prime \prime}$ is observable. However $G^{\prime}$ rises much faster and the crossover between $G^{\prime}$ and $G^{\prime \prime}$ can be considered as the gelling point measured at $1 \mathrm{~Hz}$. By the same time the values of the loss angle decrease even more markedly, sign of the increase of the elastic behaviour. The increase in the storage moduli and the reduced phase angles indicate the formation of viscoelastic gels. $G^{\prime}$ continues to increase after the gel point as more and more protein reinforces the weak tridimensional network initially formed, enhancing its elasticity.

The profile of the storage modulus is presented in Figs. 2 and 3 for different mixtures made with WPH pepsin and WPH trypsin, respectively. In all cases it is notorious that for higher amounts of LBG $(\geq 0.55 \%)$ the increase in the storage modulus during the transition from the "solution" state to the "gel" state is much smaller than for lower amounts of LBG. In fact, the more LBG is added, the more viscous the solutions, and as such the gelation process starts with a higher $G^{\prime}$. Besides, the resulting gels have a less pronounced elastic character as the final values of $\tan \delta$ are higher (Table 1). 


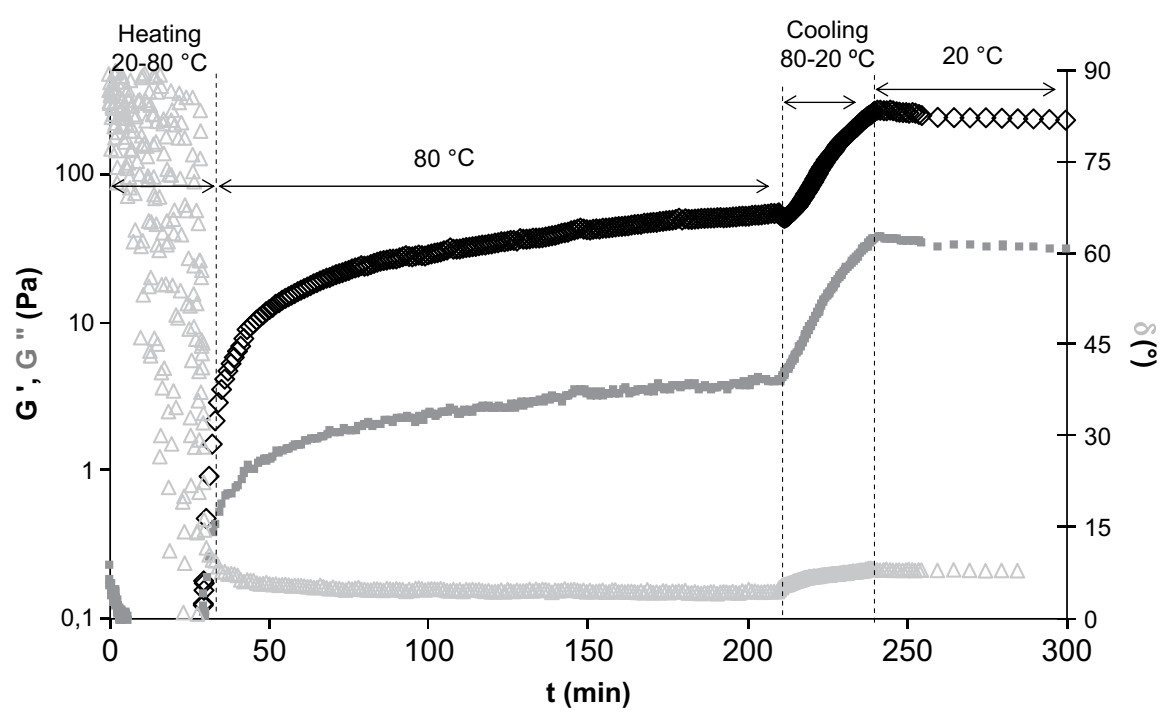

Fig. 1. Time evolution of the viscoelastic moduli and loss angle for whey protein concentrate $(10 \% \mathrm{w} / \mathrm{w})$ : black $\diamond-G^{\prime} ;$ dark grey $\bigcirc-G^{\prime \prime}$; light grey $\triangle-\delta$.

Although the overall gelation patterns are similar for all tested samples the corresponding gelling parameters $\left(G^{\prime}, G^{\prime \prime}, \delta, T g, t g\right)$ are quite different.

In the case of hydrolysates alone, $G^{\prime}$ was higher for P1.5 (657 Pa) followed by T1.0 (225 Pa). These hydrolysates were stronger than WPC at this concentration $\left(G^{\prime}=204 \mathrm{~Pa}\right)$ indicating that they were stiffer. The strength of the gels from whey proteins was thus improved for the hydrolysates with lower degree of hydrolysis (1.0\% for tryptic hydrolysates and $1.5 \%$ for peptic hydrolysates). Higher degree of hydrolysis impaired the gelation, as expected. Apparently pepsin is more effective in improving the gelling ability of whey protein gels than trypsin (although $D H$ is not exactly the same), possibly because $\beta$ - $\operatorname{Lg}$ (the main gelling protein) is resistant to pepsin. In fact, P1.5 still has all the $\beta$-Lg intact (the quantification was made through reverse phase HPLC and the results are not shown). This improvement might be due either to the presence of low molecular weight hydrophilic peptides which can reduce electrostatic repulsions between intact $\beta$ - $\mathrm{Lg}$ molecules enhancing protein-protein interaction (by hydrophobic and/or disulphide bonds) or to the partial unfolding of $\alpha$-La and BSA exposing their hydrophobic residues, therefore improving their individual gelling ability and/or allowing for a better interaction with the intact $\beta$-Lg. In the case of tryptic hydrolysates, it has been referred that limited proteolysis releases several peptide domains from the central core domain of $\beta$-Lg (e.g. Chen, Swaisgood, \& Foegeding, 1994). These domains have high hydrophobicity and interactions between these
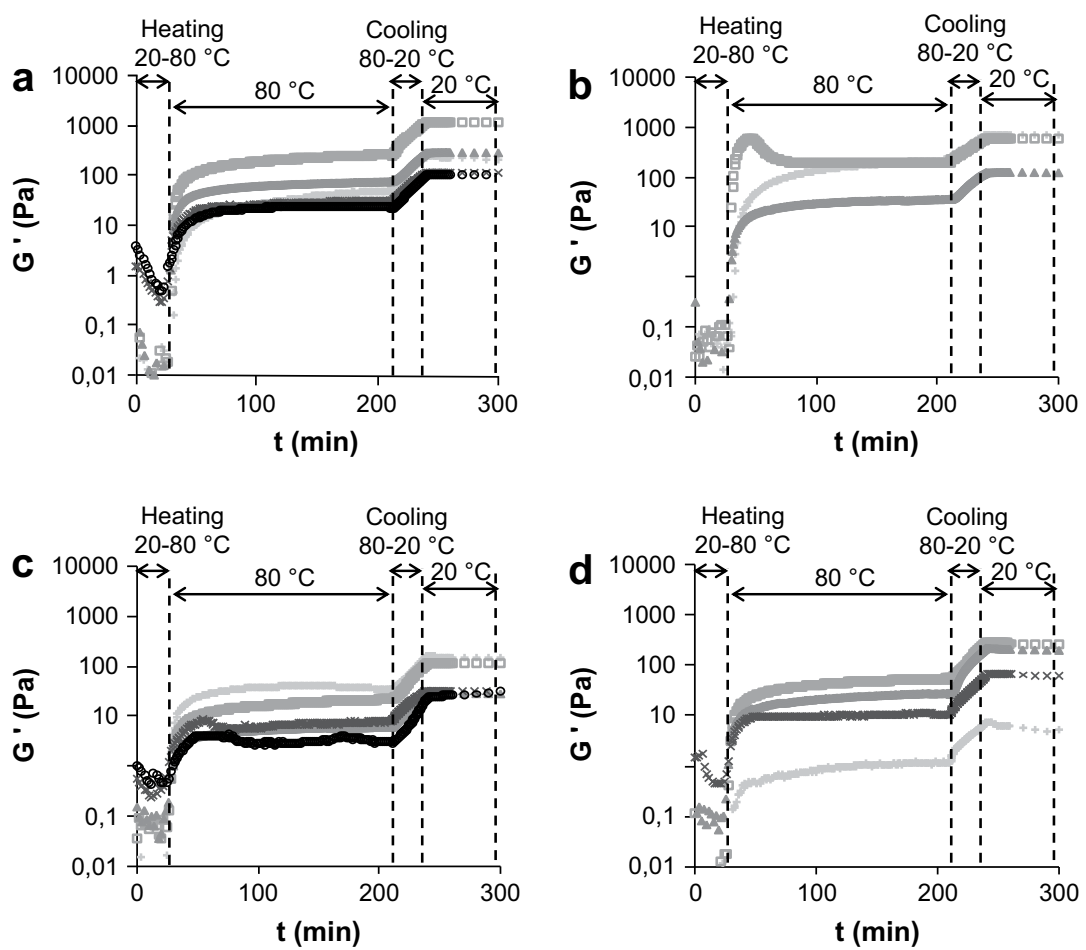

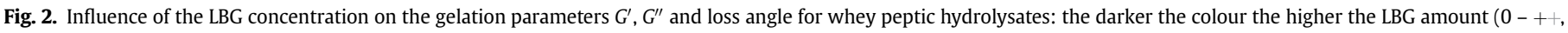
$0.1 \%-\square, 0.3 \%-\wedge, 0.55 \%-\times, 0.8 \%$ - o): a) WPC 10\% (w/w); b) P1.5 10\% (w/w); c) P2.5 10\% (w/w); d) P4.9 $16.5 \%(w / w)$. 

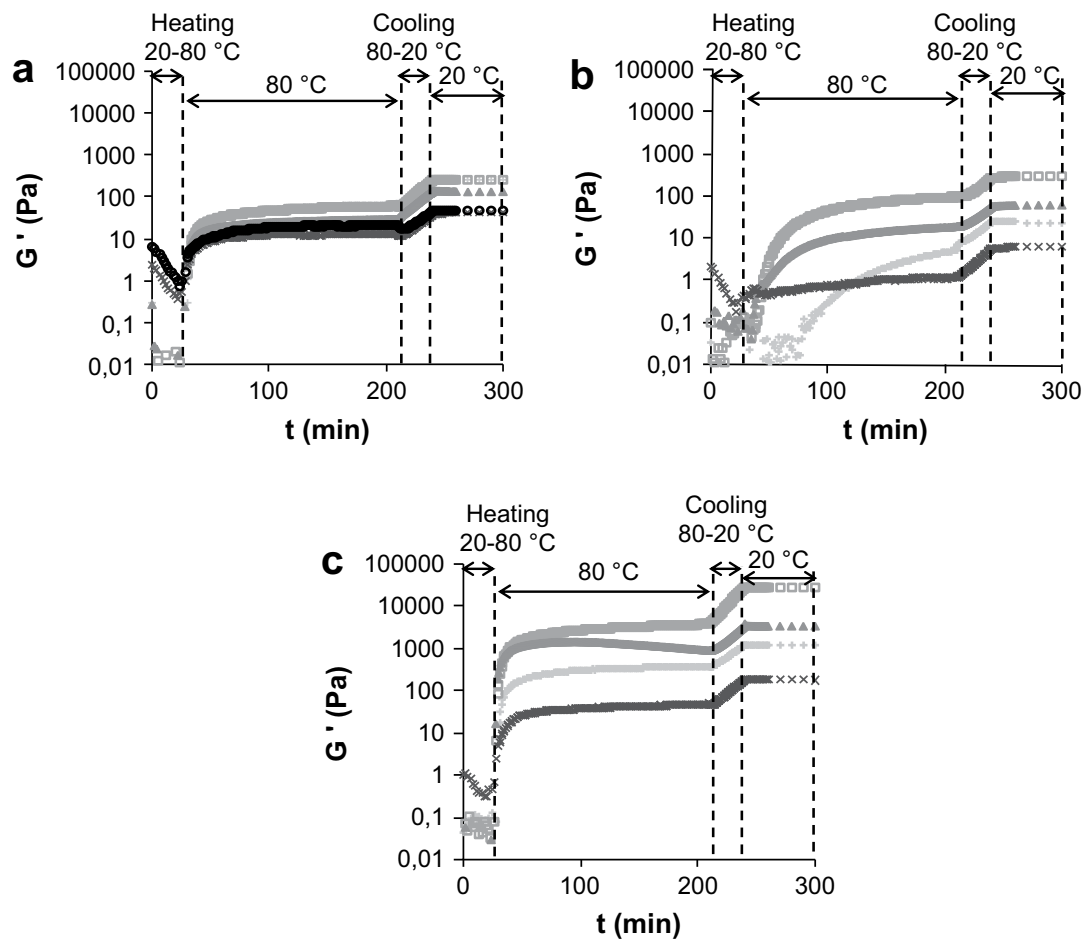

Fig. 3. Influence of the LBG concentration on the gelation parameters $G^{\prime}, G^{\prime \prime}$ and loss angle for whey tryptic hydrolysates: the darker the colour the higher the LBG amount $(0$ - lighter grey $, 0.1 \%-\sqsubset, 0.3 \%-\Lambda, 0.55 \%-x, 0.8 \%-$ black ○): a) T1.0 10\% (w/w); b) T3.5 13\% (w/w); c) T1.0 13\% (w/w).

Table 1

Influence of the LBG concentration and hydrolysis degree on some rheological parameters for whey protein hydrolysates.

\begin{tabular}{|c|c|c|c|c|c|c|c|c|c|c|}
\hline \multicolumn{2}{|c|}{$\begin{array}{l}\text { Hydrolysate } \\
(\% \mathrm{w} / \mathrm{w})\end{array}$} & \multirow{2}{*}{$\begin{array}{l}\text { LBG }(\% \mathrm{w} / \mathrm{w}) \\
0\end{array}$} & \multirow{2}{*}{$\begin{array}{l}\text { DH (\%) } \\
0\end{array}$} & \multirow{2}{*}{$\begin{array}{l}G^{\prime}(\mathrm{Pa}) \\
204 \pm 33\end{array}$} & \multirow{2}{*}{$\begin{array}{l}G^{\prime \prime}(\mathrm{Pa}) \\
28.6 \pm 3.8\end{array}$} & \multirow{2}{*}{$\begin{array}{l}\tan \delta \\
0.14 \pm 0.00\end{array}$} & \multirow{2}{*}{$\begin{array}{l}\operatorname{Tg}\left({ }^{\circ} \mathrm{C}\right) \\
79.5 \pm 0.0\end{array}$} & \multirow{2}{*}{$\begin{array}{l}\operatorname{tg}^{\mathrm{a}}(\min ) \\
-\end{array}$} & \multirow{2}{*}{$\begin{array}{l}\gamma c(\%) \\
1.8\end{array}$} & \multirow{2}{*}{$\begin{array}{l}\gamma r(\%) \\
>4.0\end{array}$} \\
\hline WPC & 10 & & & & & & & & & \\
\hline WPC & 10 & 0.1 & 0 & $1436 \pm 334$ & $207 \pm 47$ & $0.14 \pm 0.00$ & $75.2 \pm 0.1$ & - & 2.0 & $>2.8$ \\
\hline WPC & 10 & 0.3 & 0 & $596 \pm 420$ & $97.9 \pm 69.1$ & $0.17 \pm 0.00$ & $76.0 \pm 1.4$ & - & 1.6 & 10.7 \\
\hline WPC & 10 & 0.55 & 0 & $119 \pm 7$ & $30.7 \pm 1.1$ & $0.26 \pm 0.03$ & $78.9 \pm 0.6$ & - & 1.0 & 12.0 \\
\hline WPC & 10 & 0.80 & 0 & 108 & 39.0 & 0.36 & 80 & 5.43 & 1.7 & 23.4 \\
\hline P1.5 & 10 & 0 & 1.5 & 657 & 92.8 & 0.14 & 80.0 & 0.600 & $>2$ & 4.7 \\
\hline P1.5 & 10 & 0.1 & 1.5 & 588 & 105 & 0.18 & 77.6 & - & 0.2 & 7.0 \\
\hline P1.5 & 10 & 0.3 & 1.5 & 118 & 19.4 & 0.17 & 77.9 & - & 0.8 & 28.7 \\
\hline P2.5 & 10 & 0 & 2.5 & 138 & 24.8 & 0.18 & 73.7 & - & 1.2 & 2.4 \\
\hline P2.5 & 10 & 0.1 & 2.5 & 107 & 16.2 & 0.15 & 72.6 & - & 1.9 & 8.0 \\
\hline P2.5 & 10 & 0.3 & 2.5 & 27.8 & 5.00 & 0.18 & 72.4 & - & 0.8 & 6.0 \\
\hline P2.5 & 10 & 0.55 & 2.5 & 29.5 & 11.4 & 0.39 & 78.7 & - & 0.7 & 45.0 \\
\hline P2.5 & 10 & 0.8 & 2.5 & 31.5 & 13.0 & 0.41 & 80 & 12.42 & 1.0 & 625 \\
\hline P4.9 & 16.5 & 0 & 4.9 & $18.4 \pm 18.4$ & $3.35 \pm 3.04$ & $0.20 \pm 0.04$ & $80.0 \pm 0.0$ & $0.0 \pm 0.0$ & $1.1 \pm 0.5$ & $5.0 \pm 0.5$ \\
\hline P4.9 & 16.5 & 0.1 & 4.9 & 284 & 43.2 & 0.15 & 74.9 & - & 1.4 & 7.7 \\
\hline P4.9 & 16.5 & 0.3 & 4.9 & 207 & 37.3 & 0.18 & 72.8 & - & 0.8 & 7.0 \\
\hline P4.9 & 16.5 & 0.55 & 4.9 & $76.0 \pm 17.1$ & $23.8 \pm 2.3$ & $0.32 \pm 0.04$ & 80.0 & $0.598 \pm 0.002$ & 0.5 & 130 \\
\hline $\mathrm{T} 1$ & 10 & 0 & 1 & $225 \pm 25.1$ & $34.2 \pm 5.2$ & $0.15 \pm 0.01$ & $79.7 \pm 0.1$ & - & $>2$ & 4.4 \\
\hline $\mathrm{T} 1$ & 10 & 0.1 & 1 & 245 & 42.8 & 0.17 & 77.7 & - & 1.4 & 3.9 \\
\hline $\mathrm{T} 1$ & 10 & 0.3 & 1 & 126 & 20.3 & 0.16 & 76.2 & - & 1.9 & 5.6 \\
\hline $\mathrm{T} 1$ & 10 & 0.55 & 1 & 42.8 & 15.2 & 0.35 & 80.0 & 0.0 & 1.0 & 15.2 \\
\hline $\mathrm{T} 1$ & 10 & 0.8 & 1 & 45.6 & 18.7 & 0.41 & 80.0 & 8.42 & 1.1 & 26.2 \\
\hline T3.5 & 13 & 0 & 3.5 & 46.8 & 9.05 & 0.19 & 80.0 & 50.23 & $>2$ & 17.3 \\
\hline T3.5 & 13 & 0.1 & 3.5 & 312 & 57.8 & 0.19 & 80.0 & 9.42 & $>2$ & 68 \\
\hline T3.5 & 13 & 0.3 & 3.5 & 63.7 & 13.0 & 0.20 & 80.0 & 21.37 & $>2$ & - \\
\hline T3.5 & 13 & 0.55 & 3.5 & 12.2 & 5.75 & 0.55 & 80.0 & 44.27 & 1.7 & 65.8 \\
\hline $\mathrm{T} 1$ & 13 & 0 & 1 & 1080 & 171 & 0.16 & 76.6 & - & 0.4 & 0.92 \\
\hline $\mathrm{T} 1$ & 13 & 0.1 & 1 & 25530 & 3953 & 0.15 & 74.2 & - & 2.0 & $>2.0$ \\
\hline $\mathrm{T} 1$ & 13 & 0.3 & 1 & 3327 & 617 & 0.19 & 74.6 & - & 0.2 & 1.3 \\
\hline $\mathrm{T} 1$ & 13 & 0.55 & 1 & 164 & 55.9 & 0.34 & 80.0 & 1.45 & 0.6 & 51.6 \\
\hline
\end{tabular}

Values on bold were measured slightly out of the linear viscoelastic region.

Values of $G^{\prime}, G^{\prime \prime}$ and $\tan \delta$ were taken $1 \mathrm{~h}$ after the cooling temperature ramp, just before the final frequency sweep.

When the value was not reached within the experimental range used, the result is presented in the form of $>$ than the last experimental value achieved.

a Time to gelling point after the temperature ramp (after achieving $80^{\circ} \mathrm{C}$ ). 

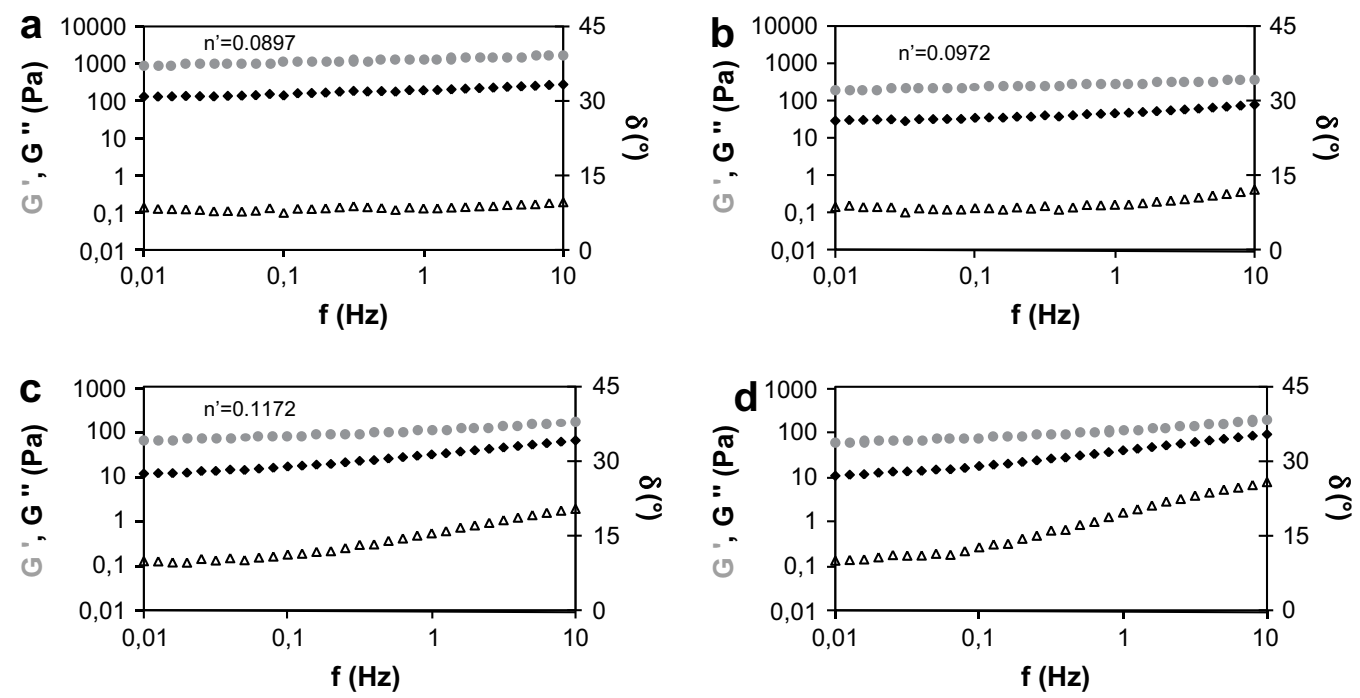

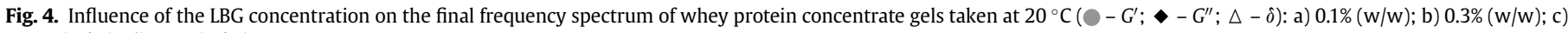
$0.55 \%(w / w) ; d) 0.8 \%(w / w)$.

domains and intact $\beta$-Lg (chemical and/or hydrophobic) can be responsible for the improvement of the $G^{\prime}$ value.

For WPC at $10 \%(w / w)$ a small amount of LBG was highly beneficial from the storage modulus point of view. However, for tryptic hydrolysates with a low degree of hydrolysis the influence of LBG is almost null and for peptic hydrolysis with low degree of hydrolysis (P1.5 and P2.5), the presence of LBG always decreased the $G^{\prime}$ value although this decrease was gentle for $0.1 \%$ and sharper for $0.3 \%$.
Critical strain was determined considering that above the deformation point at which $G^{\prime}$ varies more than $5 \%$ relatively to the initial constant $G^{\prime}$ value the viscoelastic linearity is no longer true. This criterion has been widely applied and is referred for instance by Lefebvre et al. (1998), Ould Eleya, Ko, and Gunasekaran (2004), and Pouzot, Nicolai, Durand, and Benyahia (2004). As the strain sweep was only made until $2 \%$, in most cases the critical deformation value $(\gamma c)$ was not achieved. During a stress sweep the
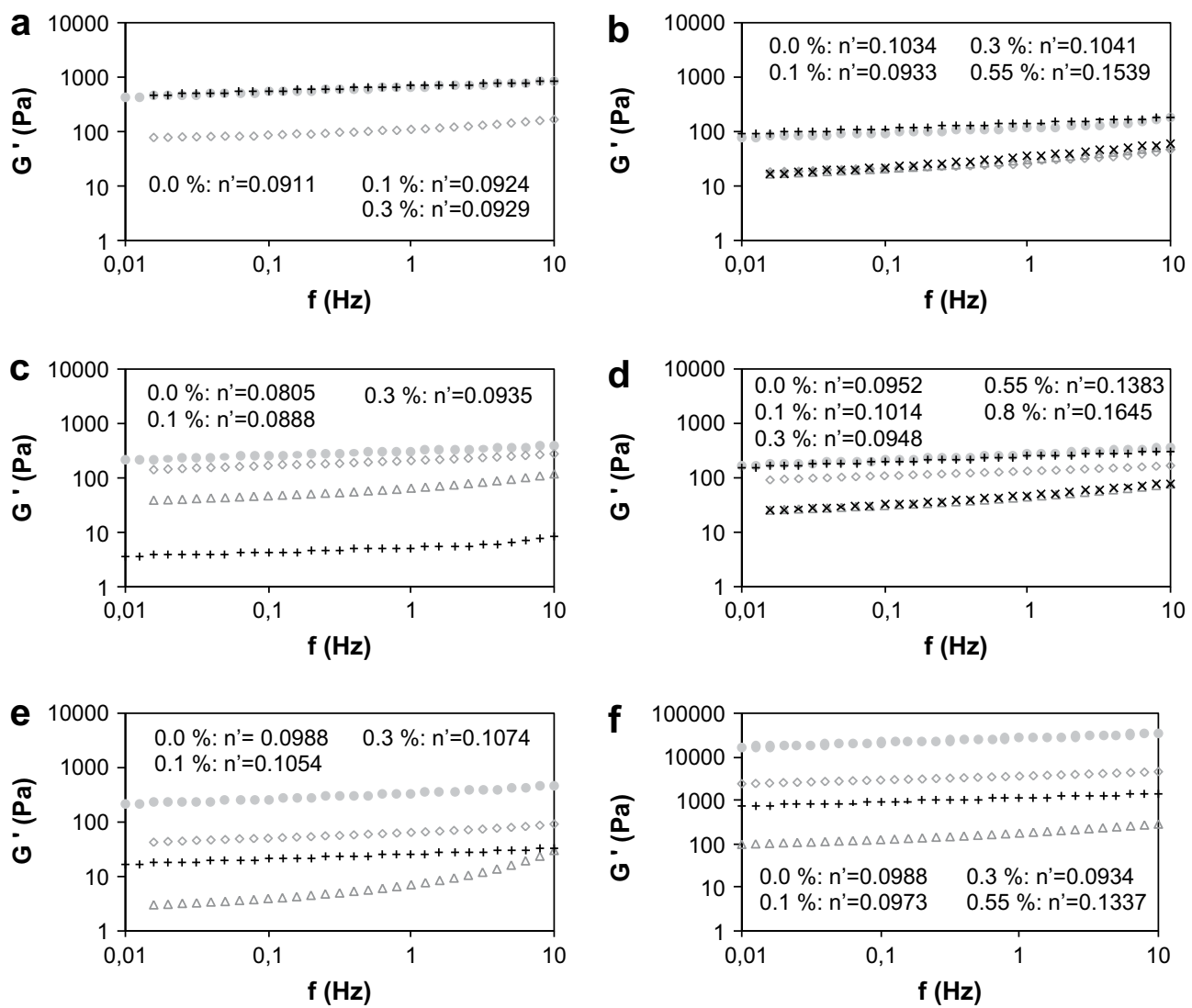

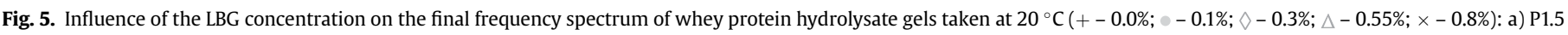
10\% (w/w); b) P2.5 10\% (w/w); c) P4.9 16.5\% (w/w); d) T1.0 10\% (w/w); e) T3.5 13\% (w/w); f) T1 13\% (w/w). 

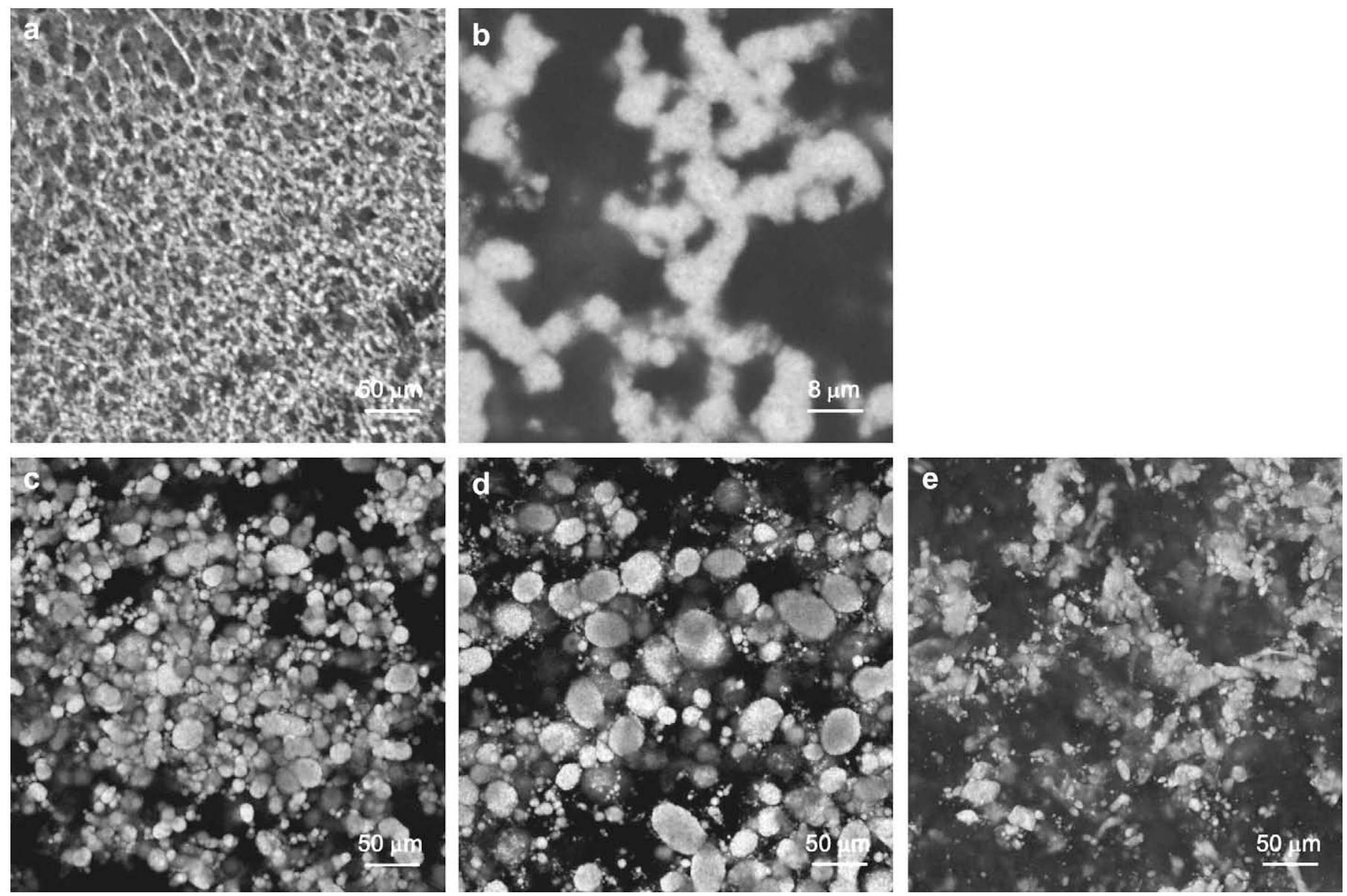

Fig. 6. Influence of the LBG on the structure of mixed WPC/LBG gels ( $10 \%$ protein): a) $0.1 \%$ of LBG; b) $0.1 \%$ LBG; c) $0.3 \%$ LBG; d) $0.55 \%$ LBG; e) $0.8 \%$ LBG.

rupture strain $(\gamma r)$ is defined as the last strain value before the start of flow characterized by a step increase in the measured strain.

The critical strains were generally lower than for WPC, reflecting a stronger gel character. The rupture strain also increased for the higher LBG concentration. A stronger viscous character was found at $0.55 \%$ of LBG for T1.0 than for WPC, with higher $\tan \delta$ and much higher rupture strain.

The experimental error associated with strain fracture measurements may be high due to the sensibility of the fracture to the presence of defects that differ between samples. This fact is more important for small volumes and is a handicap of the plate and plate geometry (Pouzot, Nicolai, Benyahia, \& Durand, 2006). This may justify small differences in behaviour verified in Table 1.

The behaviour of the more hydrolysed proteins towards the presence of LBG was more similar to that of the WPC when compared to the behaviour of the less hydrolysed proteins, although weaker gels were always obtained. In fact, the maximum gel strength was found in both cases for $0.1 \%$ LBG. The viscous character increased consistently after 0.1\% LBG, the critical strain generally decreased and the rupture strain generally increased. The gelation time increased after 0.3\% LBG for P2.5 and after 0.1\% LBG for T1.0. However the protein concentration used in these systems was much higher.

To check if the different behaviour could be ascribed to differences in concentration values or if the differences resulted from differences in the gels' microstructure, another set of mixed systems was prepared with $13 \%(\mathrm{w} / \mathrm{w}) \mathrm{T} 1.0$. In this case, notorious maximum gel strength, minimum $\tan \delta$ and minimum gelation time were found for $0.1 \%$ LBG. Thus it can be stated that the rheological behaviour of P1.5, P2.5 and T1.0 did not show well defined maximum gel strength for $0.1 \%$ possibly because the concentration was not high enough. As explained for the hydrolysates alone, the hydrolysates have probably a mixture of gelling peptides/proteins and non-gelling peptides. Thus, to achieve a similar concentration in gelling agents and, thus, a similar behaviour, it is necessary to have a higher concentration of these hydrolysates in comparison with WPC.

The mechanical spectra for $G^{\prime}, G^{\prime \prime}$ and $\delta$ of WPC gels are presented in Fig. 4. The wide zone with both moduli nearly independent on the frequency is typical of a gel character (Ross-Murphy, 1995). A flat slope is indicative of a strong, elastic gel (Foegeding et al., 2002). When the gel network bonds are of purely chemical nature $G^{\prime}$ and $G^{\prime \prime}$ are independent of the angular frequency. When physical bonds are also involved then $G^{\prime} \propto \omega^{n^{\prime}}$ holds true. In the case of protein gels this dependence exists but is minimal (Clark \& RossMurphy, 1987; Doucet et al., 2001). Both $G^{\prime}$ and $G^{\prime \prime}$ spectra have the characteristic form of a gel with non-covalent bonds, with $n^{\prime}$ higher than zero. At small enough frequencies both viscoelastic moduli are usually strongly independent of the frequency (Fig. 4). This stands for both strong and weak gels (Ross-Murphy, 1995). However, for high amounts of LBG, the slope of the storage modulus profile increases for higher frequencies (Fig. 4(c) and (d)). Thus, in these cases, $n^{\prime}$ was not calculated. This slope increase may be caused by the weaker character of the gels. Furthermore $\tan \delta$ strongly depends on the frequency which is indicative of an increasing viscous character. It is also possible that the LBG concentrations used do not lead to "real" gels but pre-gels with a high viscous character. The $\tan \delta$ dependence on the frequency increased with 

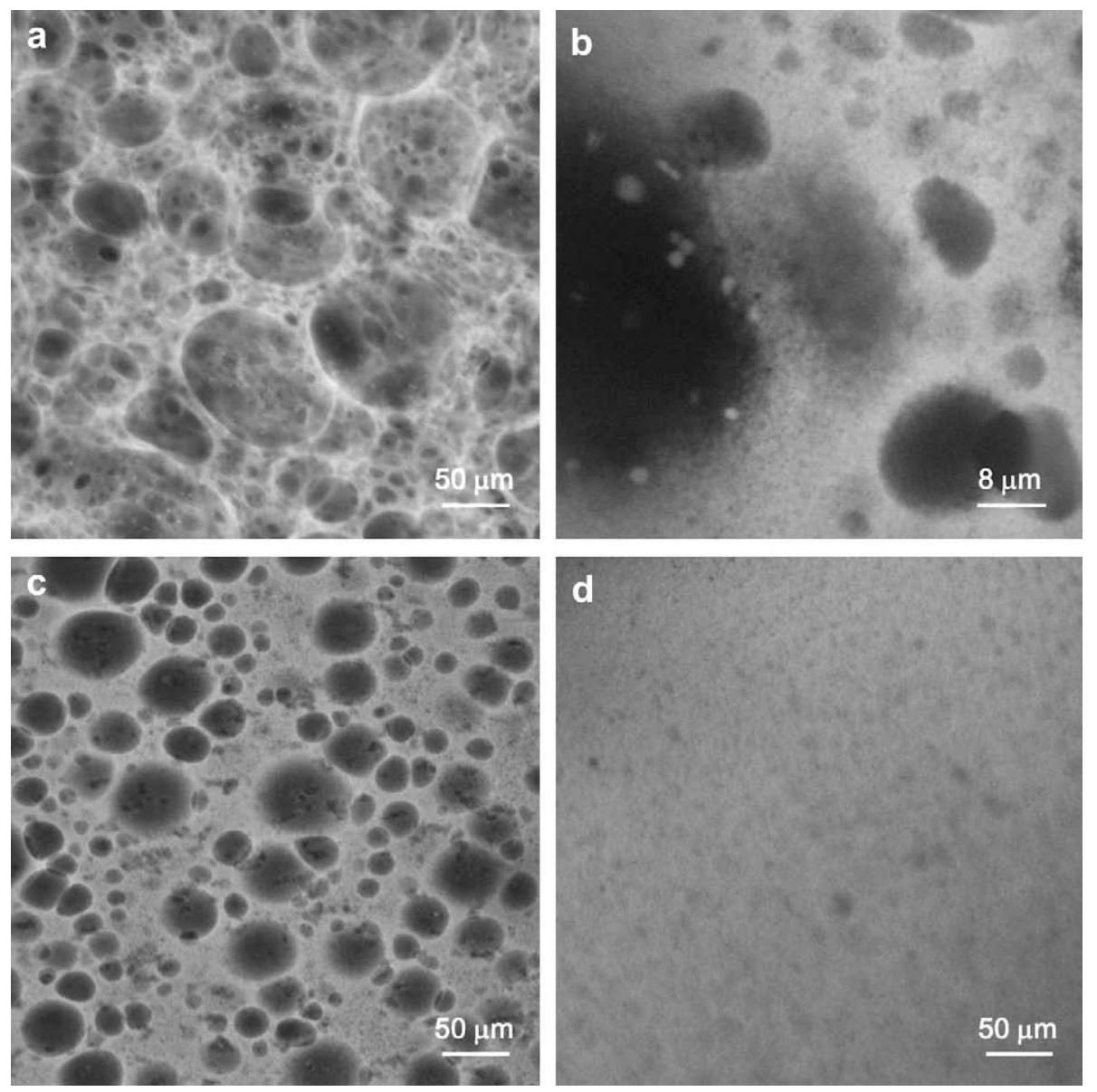

Fig. 7. Influence of the LBG on the structure of mixed P1.5/LBG gels ( $10 \%$ protein): a) $0.1 \%$ of LBG; b) $0.1 \%$ LBG; c) $0.55 \%$ LBG; d) $0 \%$ LBG.

the increase on LBG concentration. This is in agreement with the microstructure described below for these systems.

Nevertheless, the value of $n^{\prime}$ increases with the increase of the LBG concentration, indicating a possible increased importance of non-covalent interactions.

Gels from hydrolysates with LBG showed similar frequency spectra. $G^{\prime}$ and $\tan \delta$ were almost constant over a wide range of frequencies. The slope of the $G^{\prime}$ spectrum was not zero (though very low) indicating that non-covalent interactions play a role in the gel structure. Once again, for higher LBG concentrations, $\tan \delta$ increased with the frequency. The values for $n^{\prime}$ are presented in Fig. 5. For lower LBG concentration $(0.1-0.3 \% \mathrm{w} / \mathrm{w}) n^{\prime}$ was approximately constant indicating that, although the microstructure of these gels changed, the relevance of non-covalent forces was the same.

\subsection{Interplay of structure and mechanical properties}

The microstructural analysis revealed the phase-separated character, as expected. The addition of LBG led always to some degree of phase separation (Figs. 6-9) with LBG promoting protein aggregation. One phase is rich in protein (the whiter phase) and the other is protein-depleted and possibly enriched with polysaccharide (the darker phase).

Thermodynamic incompatibility between whey proteins and neutral polysaccharides has been widely reported (e.g. Grinberg \& Tolstoguzov, 1997; Syrbe, Bauer, \& Klostermeyer, 1998; Syrbe, Fernandes, Dannenberg, Bauer, \& Klostermeyer, 1995). In the case of native whey proteins this incompatibility may be restricted to a specific pH range (e.g. 5-7) and to high concentrations of the polysaccharide (Syrbe et al., 1998). For a mixture of a gelling biopolymer and a non-gelling biopolymer, segregative interactions can lead to higher gel strength. In fact synergistic effects have been referred for guar gum (Fitzsimons, Mulvihill, \& Morris, 2008), xanthan (Bryant \& McClements, 2000), cassia gum (Gonçalves, Torres, et al., 2004), tara gum (Sittikijyothin, Sampaio, \& Gonçalves, 2007), pectin (Beaulieu, Turgeon, \& Doublier, 2001) or locust bean gum (Tavares \& da Silva, 2003). At low polysaccharide concentrations the segregative phase separation can also give rise to an increment of the protein concentration, increasing the elastic response if the connectivity between the protein aggregates is not affected. Thus the effect of a polysaccharide on the gelation of a protein depends on the nature of the polysaccharide, on the $\mathrm{pH}$, on the ionic strength, on the temperature treatment and on the concentrations used (Olsson, Langton, \& Hermansson, 2002).

The CSML photos of the samples with $0 \%$ LBG were quite similar and it was only presented the photo for P1.5 at 0\% (Fig. 7d).

For WPC with $0.1 \%$ LBG a bicontinuous microstructure is observed (Fig. 6a, b). There is a three dimensional stranded network of WPC enriched globules with typical size for strands of the order of $50 \mu \mathrm{m}$. As the LBG concentration increased the microstructure became less stranded as the protein globules are larger and more spherical (Fig. 6c, d). The phase separation is more evident, a larger polydispersity in the size of globules is observed and the volume occupied by the enriched protein phase decreases (see Table 2 ). The globules are grouped in large clusters first and then, with a further increase of LBG, in smaller clusters but with bigger globules. Further increases of LBG resulted in the shrinkage of the spherical protein domains probably with higher protein concentration 

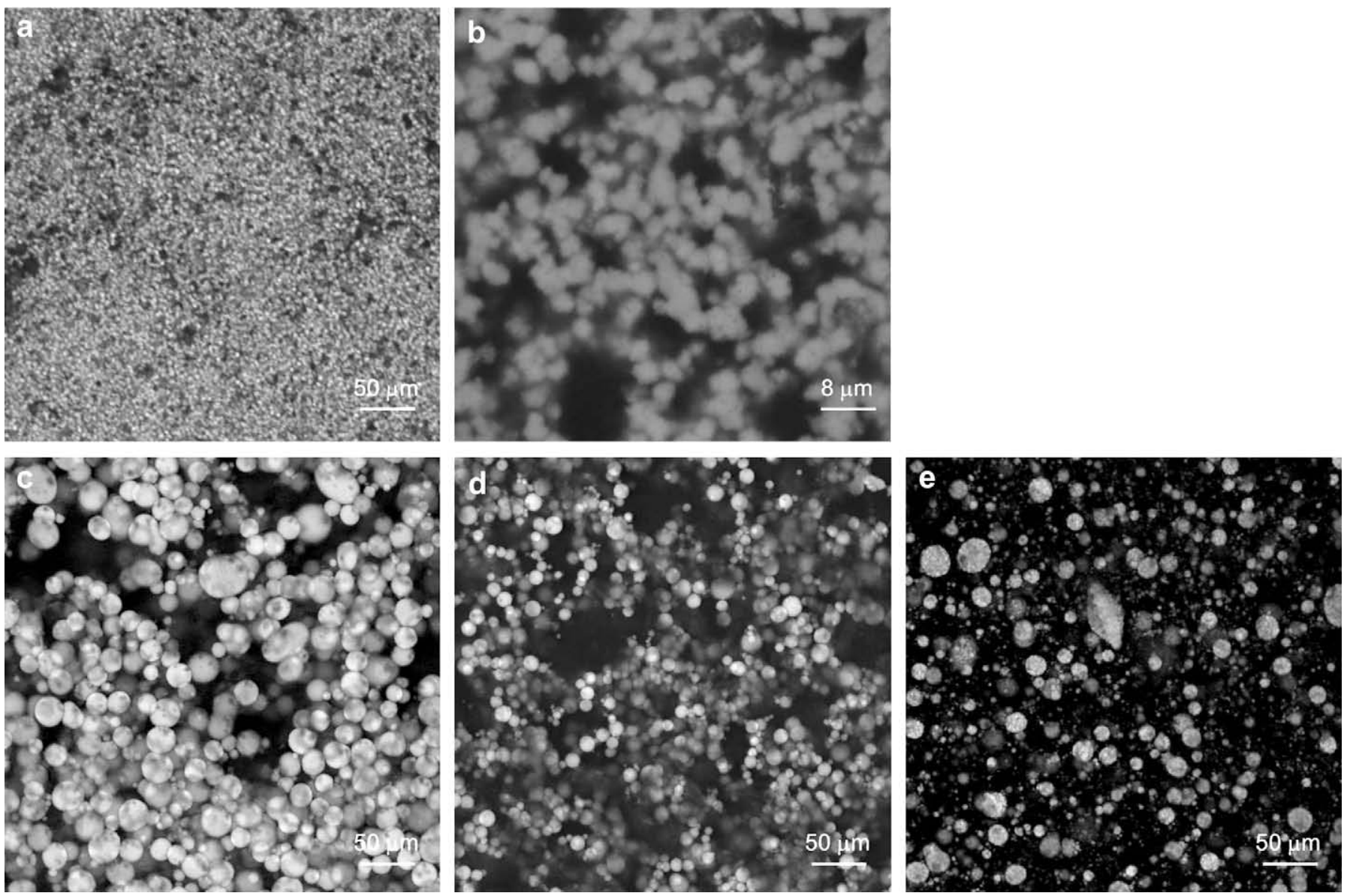

Fig. 8. Influence of the LBG on the structure of mixed P2.5/LBG gels ( $10 \%$ protein): a) $0.1 \%$ of LBG; b) $0.1 \%$ LBG; c) $0.3 \%$ LBG; d) $0.55 \%$ LBG; e) $0.8 \%$ LBG.

(Fig. 6e). Even further increases would probably lead to the collapse of the gel structure. These structural changes are reflected in the rheological properties of the final gels (Table 1 ). For very low LBG content $(0.1 \%)$, the phase separation caused an increase in the concentration of protein in one of the continuous phases that subsequently increased the elastic response of the network. For $0.3 \%$ LBG, although the protein concentration is probably further increased in the protein-enriched phase, the connectivity of the network is worsened and the storage modulus decreased even though the resulting $G^{\prime}$ is still higher than that of the gel with no polysaccharide. For the same amount of LBG, the loss tangent starts increasing indicating an increment in the viscous character relatively to the elastic character. At $0.5 \%$ LBG the protein-enriched globules are very large and polydisperse in size and the connectivity of the structure was further reduced, as well as the storage modulus. At $0.8 \%$ the big globules seem to start collapsing into numerous smaller globules. Accordingly, the viscous character of the latter structural morphology is further increased, though the storage modulus was not significantly reduced. The temperature at which gelation occurred (in the heating conditions used) follows a similar behaviour. It decreases from 0 to $0.1 \%$ LBG (sometimes $0.3 \%$ ) corresponding to the increase of protein concentration in the network and then continuously increases following the decrease in the network connectivity. The critical strain also decreases whereas the rupture strain increases (at least for higher LBG amounts), indicating a more plastic character of the gel (Table 1). These findings are in agreement with the weakening of the gel microstructure. Eventually at higher LBG concentrations the system would fully collapse and no gel would form.
A maximum storage modulus for very low concentrations of non-gelling polyssacharides was also reported by other authors. Fitzsimons et al. (2008) found an optimum concentration of $0.1 \%$ $(\mathrm{w} / \mathrm{w})$ guar gum with a 12-fold enhancement in gel strength in comparison with WPI alone. de Jong and van de Velde (2007) found maximum values for all large deformation parameters around 0.1$0.15 \%(\mathrm{w} / \mathrm{w})$ for mixed systems with guar or LBG. A similar trend is also reported for $\kappa$-carrageenan at $\mathrm{pH} 7$ and an ionic strength of 0.1-0.15 M by Capron, Nicolai, and Smith (1999) and Neiser, Draget, and Smidsrod (2000), with a maximum gel strength for $0.1-0.3 \% \kappa-$ carrageenan. Although this is a gelling anionic polysaccharide the behaviour seems to be ruled also by aggregation and demixing kinetics as in the present case.

Tavares and da Silva (2003) report a different trend with the increase of LBG concentration. In fact, they refer a continuous increase of the WPI gel strength with the increase of LBG concentration at $\mathrm{pH}$ 7. Nevertheless, no salt was added and the ionic strength was probably much lower. It remains to enlighten if at a higher LBG concentration the effect would reverse or if there is no optimum for very low ionic strength. The presence of salt screens electrostatic repulsion between the protein globules and allows further aggregation and larger clusters. Thus phase separation is further promoted. The absence of salt will probably delay the phase separation (in comparison with the former case), and the maximum gel strength will probably be achieved for much higher LBG concentrations. In fact, micrographs presented later by the same group of authors (Monteiro, Tavares, Evtuguin, Moreno, \& da Silva, 2005) show that phase separation is very low for $0.25 \%$ LBG and more significant for $0.70 \%$ LBG. Even so, this phase separation is 

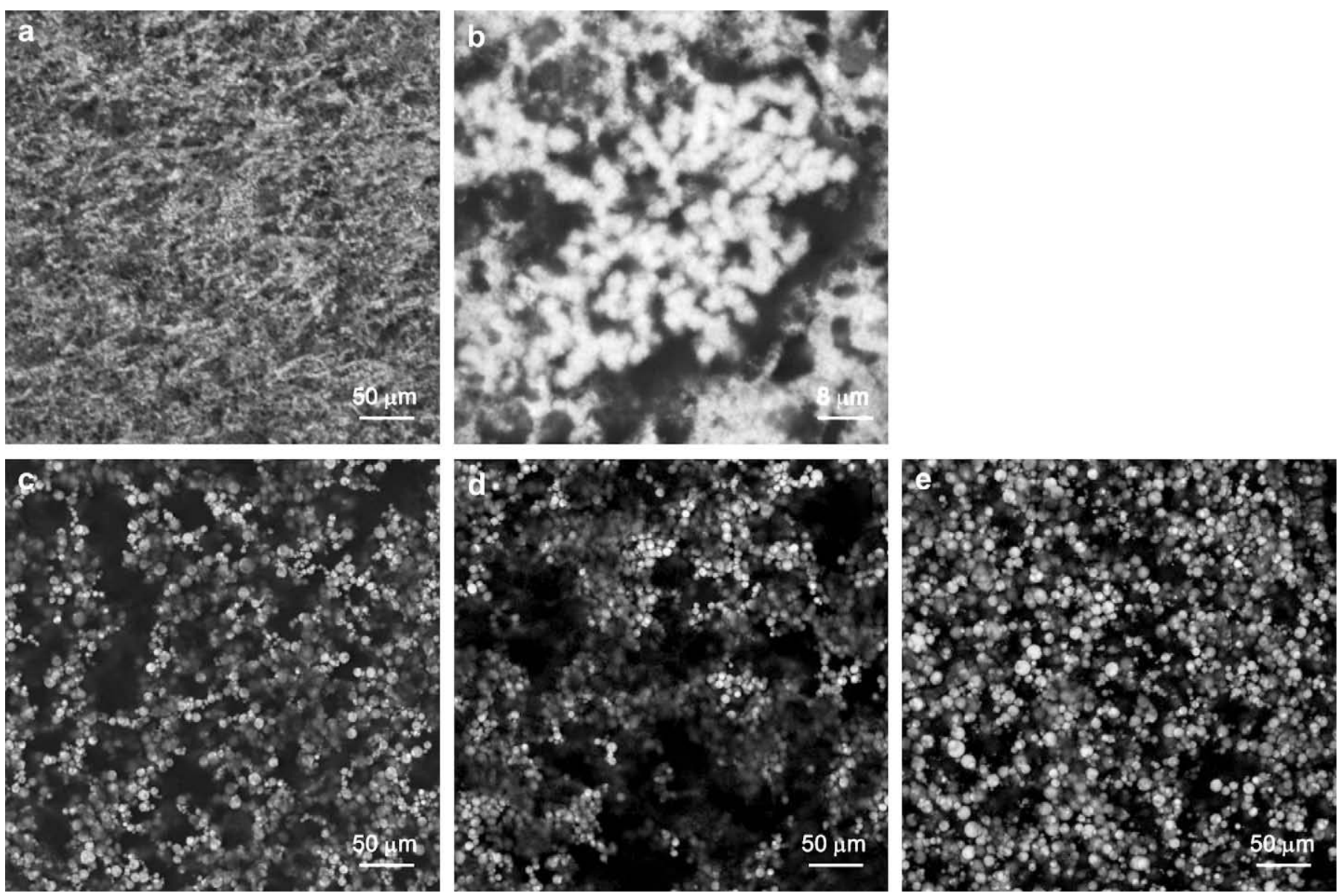

Fig. 9. Influence of the LBG on the structure of mixed T1/LBG gels ( $10 \%$ protein): a) $0.1 \%$ of LBG; b) $0.1 \%$ LBG; c) $0.3 \%$ LBG; d) $0.55 \%$ LBG; e) $0.8 \%$ LBG.

only comparable to the phase separation at $0.1 \%$ LBG in the presence of $0.1 \mathrm{M}$ salt. Similar results are achieved by Sittikijyothin et al. (2007) with $\beta-\operatorname{Lg}(6.5 \% \mathrm{w} / \mathrm{w})$ and tara gum $(0-0.56 \% \mathrm{w} / \mathrm{w})$ at $\mathrm{pH} 7$ and low ionic strength.

Gels from whey protein peptic hydrolysates with $1.5 \%$ of hydrolysis had a different microstructure (Fig. 7). Although phase separation was also present, a continuous phase enriched in protein and a discontinuous phase (possibly enriched in LBG) were observed (Fig. 7a, b). The visible micro-phase separation was lower and the protein phase seems to be highly stranded or with very small aggregates both not visible at a micrometer scale (a TEM microscope would have been more suitable). The inclusion of LBG probably "cleaved" some strands resulting in a more "porous" protein phase but the phase separation also probably increased the protein phase concentration. The change in the gel strength in the presence of $0.1 \%$ LBG was not significant (Table 1 ). The system was very sensitive to strain changes (as some measurements were made out of the linear viscoelastic region) and the $0.5 \%$ strain value used probably affected the microstructure of the gel, breaking some protein aggregates and resulting in a $G^{\prime}$ corresponding to a lower "measured" gel strength than the effective one. For a higher LBG concentration the boundaries of the discontinuous phase became sharper. The area of the protein network decreased as well as the gel strength.

Peptic hydrolysates with a degree of hydrolysis of $2.5 \%$ led also to a bicontinuous microstructure in the presence of $0.1 \%(w / w)$ LBG as in the case of WPC (Fig. 8a, b). However the protein strands are thinner and shorter, appearing that the structure was partially broken by the "phase separation". Thus the resulting storage modulus decreased slightly in comparison to the $G^{\prime}$ of the P2.5 gel in the absence of polysaccharide. It seems quite possible that lower LBG amounts would lead to lower phase separation and to a strengthening of the gel microstructure. Increasing the LBG amount to $0.3 \%$ led to the formation of big spherical protein microdomains with very sharp boundaries (Fig. 8c). These spherical protein microdomains seem to be roughly connected with each other forming clusters that sustain the coarse gel structure. Further increase in the LBG concentration resulted in the shrinkage of the big spheres due to further depletion of LBG, causing further increase of protein concentration inside the microdomains (Fig. 8d).

This difference in behaviour between low and high amounts of LBG is also reflected in the volume occupied by the proteinenriched phase. In fact, it can be seen that this volume was highly reduced between the samples with $0.1 \%$ LBG (sometimes $0.3 \%$ ) and samples with higher LBG concentration (Table 2). The gel coarsened and became even weaker. A further increase of LBG to $0.8 \%$ causes

Table 2

Influence of the LBG concentration on the relative volume of the enriched phase in protein in mixed whey protein or hydrolysates $(10 \% \mathrm{w} / \mathrm{w}) / \mathrm{LBG}$ heat-set gel systems.

\begin{tabular}{lllll}
\hline & \multicolumn{4}{l}{ Relative volume of the enriched phase in protein $(\%)$} \\
\cline { 2 - 5 } LBG $(\% \mathrm{w} / \mathrm{w})$ & 0.1 & 0.3 & 0.55 & 0.8 \\
\hline WPC & 40 & 31 & 27 & 23 \\
P1.5 & 46 & - & 38 & - \\
P2.5 & 45 & 41 & 23 & 16 \\
T1.0 & 43 & 22 & 20 & 27 \\
\hline
\end{tabular}


the collapse of the clusters (Fig. 8e). As the LBG phase is supposedly non-gelling, a system with these characteristics should show a liquid behaviour. However the mechanical behaviour of P2.5 with $0.8 \%$ LBG seems to be typical of a gel, although with a strong viscous character with a high value of $\tan \delta$, a low storage modulus and a high rupture strain. The storage modulus had even a very slight increase (although this increase is probably related to the increase in the viscous character as $\tan \delta$ also increases). Neiser et al. (2000) also referred a minimum of the storage modulus at $0.6 \%$ carrageenan followed by a slight increase. Either the system is a liquid with a very large relaxation time causing the $G^{\prime}$ curve to cross $G^{\prime \prime}$ for very low frequencies and behaving like a gel at the tested frequency $(1 \mathrm{~Hz})$ or the system is indeed a very weak gel. In this case, this could mean that LBG could form weak gels under the present environmental conditions. In short, for P2.5 the strength of the gel and the gelation time decreased with the increase of the LBG amount (except for the highest value where other phenomena seem to be involved).

Tryptic hydrolysates with a degree of hydrolysis of $1.0 \%$ had a similar behaviour. At $0.1 \%$ LBG a bicontinuous microstructure was observed (Fig. 9a, b). Connectivity was severely damaged with the additional increase of LBG concentration. The small spherical protein-enriched microdomains connected in coarse clusters. Higher LBG concentrations (0.3 and $0.55 \%)$ decreased the microdomains size; the clusters became denser and the volume of the phase between the clusters had a minor increase; the protein concentration within the microdomains probably also increased (Fig. 9c, d). Increasing LBG concentration to $0.8 \%$ resulted in slightly larger aggregates hardly connected with each other (Fig. 9e).

Although no influence in the gel strength was visible for T1.0 with $0.1 \%(\mathrm{w} / \mathrm{w})$ LBG (only a slight increase, within the experimental error), the gelation time, the critical strain and the rupture strain were all reduced (Fig. 3; Table 1). Further increases in the LBG concentration caused weakening of the gels, increased viscous character (increased $\tan \delta$ ) and increased rupture strain. However, when the structure changed from coarsely bicontinuously stranded to highly particulated, the gelation time was further decreased and only then it started to increase, probably because the increase in the viscous character only then prevailed over the reducing effect of LBG on the time for gelation.

P2.5 and T1.0 protein microdomains were more spherical than WPC microdomains when the structure was highly particulated. WPC and P2.5 spherical microdomains were much bigger and with a broader size distribution than T1.0 spherical domains. Phase separation was more severe in P2.5 mixed systems.

The lower value of $\gamma c$ for higher amounts of LBG (ca. $0.55 \%$ ) found for both WPC and hydrolysates can indicate that the system is approaching a colloidal behaviour, with bigger clusters as referred by Clark and Ross-Murphy (1987).

\section{Conclusion}

For a protein concentration of $10 \%(\mathrm{w} / \mathrm{w})$, mild hydrolysis (up to $2.5 \%$ in the case of peptic hydrolysates and to $1.0 \%$ in the case of tryptic hydrolysates) ameliorates the gelling ability of whey proteins.

LBG alters the microstructure of whey protein gels by modifying the equilibrium between aggregation and segregation. The gelation time is also decreased in the presence of very low amounts of LBG (up to $0.1-0.3 \%$ ). The volume of the protein-enriched phase decreases with the increase of the LBG concentration and the protein concentration probably increases within that phase. For higher LBG concentrations, the gelation time is increased. The final structure of the gels is a result of the equilibrium between aggregation and segregation and of the increase of the protein concentration on the protein-enriched phase.

The WPC synergism with LBG is affected by the protein hydrolysis. For a protein concentration of $10 \%(\mathrm{w} / \mathrm{w})$, no maximum value was found in the $G^{\prime}$ dependence on LBG content in the case of the hydrolysates, unlike the intact WPC. However, for higher protein concentrations, the behaviour of gels from whey proteins or whey protein hydrolysates towards the presence of LBG is very similar. In this case, a small amount of LBG in the presence of salt leads to a big enhancement in the gel strength.

It is possible to make all kinds of different gels (fast gelling, slow gelling, hard and stiff, weak, stranded, particulated, ...) by manipulating the protein concentration, the degree of hydrolysis, the amount of LBG and the salt content. It is important though to master the mechanism of phase separation in order to be able to design the adequate conditions for the desired texture.

\section{References}

Adler-Nissen, J. (1979). Determination of the degree of hydrolysis of food protein hydrolysates by trinitrobenzenesulfonic acid. Journal of Agricultural and Food Chemistry, 27(6), 1256-1262.

Baeza, R. I., Carp, D. J., Perez, O. E., \& Pilosof, A. M. R. (2002). Kappa-carrageenanprotein interactions: effect of proteins on polysaccharide gelling and textural properties. Lebensmittel-Wissenschaft Und-Technologie - Food Science and Technology, 35(8), 741-747.

Beaulieu, M., Turgeon, S. L., \& Doublier, J. L. (2001). Rheology, texture and microstructure of whey proteins/low methoxyl pectins mixed gels with added calcium. International Dairy Journal, 11(11-12), 961-967.

Bertrand, M. E., \& Turgeon, S. L. (2007). Improved gelling properties of whey protein isolate by addition of xanthan gum. Food Hydrocolloids, 21(2), 159-166.

Bryant, C. M., \& McClements, D. J. (2000). Influence of xanthan gum on physical characteristics of heat-denatured whey protein solutions and gels. Food Hydrocolloids, 14(4), 383-390.

Capron, I., Nicolai, T., \& Durand, D. (1999). Heat induced aggregation and gelation of beta-lactoglobulin in the presence of kappa-carrageenan. Food Hydrocolloids, 13(1), 1-5.

Capron, I., Nicolai, T., \& Smith, C. (1999). Effect of addition of [kappa]-carrageenan on the mechanical and structural properties of [beta]-lactoglobulin gels. Carbohydrate Polymers, 40(3), 233-238.

Chen, S. X., Swaisgood, H. E., \& Foegeding, E. A. (1994). Gelation of beta-lactoglobulin treated with limited proteolysis by immobilized trypsin. Journal of Agricultural and Food Chemistry, 42(2), 234-239.

Clark, A., \& Ross-Murphy, S. B. (1987). Structural and mechanical properties of biopolymer gels. (pp. 57-192). Biopolymers. Berlin: Springer-Verlag.

Croguennoc, P., Nicolai, T., Durand, D., \& Clark, A. (2001). Phase separation and association of globular protein aggregates in the presence of polysaccharides: 2 Heated mixtures of native beta-lactoglobulin and k-carrageenan. Langmuir 17(14), 4380-4385.

Dickinson, E. (1997). Enzymic crosslinking as a tool for food colloid rheology control and interfacial stabilization. Trends in Food Science E Technology, 8(10), 334-339.

Doucet, D., Gauthier, S. F., \& Foegeding, E. A. (2001). Rheological characterization of a gel formed during extensive enzymatic hydrolysis. Journal of Food Science, 66(5), 711-715.

Fitzsimons, S. M., Mulvihill, D. M., \& Morris, E. R. (2008). Large enhancements in thermogelation of whey protein isolate by incorporation of very low concentrations of guar gum. Food Hydrocolloids, 22(4), 576-586.

Foegeding, E. A., Davis, J. P., Doucet, D., \& McGuffey, M. K. (2002). Advances in modifying and understanding whey protein functionality. Trends in Food Science E' Technology, 13(5), 151-159.

Gonçalves, M. P., Sittikijyothin, W., da Silva, M. V., \& Lefebvre, J. (2004). A study of the effect of locust bean gum on the rheological behaviour and microstructure of a beta-lactoglobulin gel at pH 7. Rheologica Acta, 43(5), 472-481.

Gonçalves, M. P., Torres, D., Andrade, C. T., Azero, E. G., \& Lefebvre, J. (2004). Rheological study of the effect of Cassia javanica galactomannans on the heatset gelation of a whey protein isolate at pH 7. Food Hydrocolloids, 18(2), 181-189.

Gosal, W. S., \& Ross-Murphy, S. B. (2000). Globular protein gelation. Current Opinion in Colloid $\mathcal{E}$ Interface Science, 5(3-4), 188-194.

Grinberg, V. Y., \& Tolstoguzov, V. B. (1997). Thermodynamic incompatibility of proteins and polysaccharides in solutions. Food Hydrocolloids, 11(2), 145-158.

Guan, X., Yao, H. Y., Chen, Z. X., Shan, L. A., \& Zhang, M. D. (2007). Some functional properties of oat bran protein concentrate modified by trypsin. Food Chemistry, 101(1), 163-170.

Hines, M. E., \& Foegeding, E. A. (1993). Interactions of alpha-lactalbumin and bovine serum-albumin with beta-lactoglobulin in thermally induced gelation. Journal of Agricultural and Food Chemistry, 41(3), 341-346.

Huang, X. L., Catignani, G. L., Foegeding, E. A., \& Swaisgood, H. E. (1994). Comparison of the gelation properties of beta-lactoglobulin genetic variant-A and variant-B. Journal of Agricultural and Food Chemistry, 42(5), 1064-1067. 
Huang, X. L., Catignani, G. L., \& Swaisgood, H. E. (1999). Modification of rheological properties of whey protein isolates by limited proteolysis. Nahrung - Food, 43(2), 79-85.

de Jong, S., \& van de Velde, F. (2007). Charge density of polysaccharide controls microstructure and large deformation properties of mixed gels. Food Hydrocolloids, 21(7), 1172-1187.

Kang, I. J., Matsumura, Y., Ikura, K., Motoki, M., Sakamoto, H., \& Mori, T. (1994). Gelation and gel properties of soybean glycinin in a transglutaminase-catalyzed system. Journal of Agricultural and Food Chemistry, 42(1), 159-165.

Kavanagh, G. M., Clark, A. H., Gosal, W. S., \& Ross-Murphy, S. B. (2000). Heat-induced gelation of beta-lactoglobulin/alpha-lactalbumin blends at $\mathrm{pH} 3$ and $\mathrm{pH} 7$. Macromolecules, 33(19), 7029-7037.

Kavanagh, G. M., Clark, A. H., \& Ross-Murphy, S. B. (2000). Heat-induced gelation of globular proteins: 4. Gelation kinetics of low pH beta-lactoglobulin gels. Langmuir, 16(24), 9584-9594.

Lefebvre, J., Renard, D., \& Sanchez-Gimeno, A. C. (1998). Structure and rheology of heat-set gels of globular proteins - I. Bovine serum albumin gels in isoelectric conditions. Rheologica Acta, 37(4), 345-357.

McCleary, B. V., Clark, A. H., Dea, I. C. M., \& Rees, D. A. (1985). The fine-structures of carob and guar galactomannans. Carbohydrate Research, 139, 237-260.

McPhail, D., \& Holt, C. (1999). Effect of anions on the denaturation and aggregation of beta-lactoglobulin as measured by differential scanning microcalorimetry. International Journal of Food Science and Technology, 34(5-6), 477-481.

Monteiro, S. R., Tavares, C. A., Evtuguin, D. V., Moreno, N., \& da Silva, J. A. L. (2005) Influence of galactomannans with different molecular weights on the gelation of whey proteins at neutral pH. Biomacromolecules, 6(6), 3291-3299.

Ndi, E. E., Swanson, B. G., Barbosa-Canovas, G. V., \& Luedecke, L. O. (1996). Rheology and microstructure of beta-lactoglobulin sodium polypectate gels. Journal of Agricultural and Food Chemistry, 44(1), 86-92.

Neiser, S., Draget, K. I., \& Smidsrod, O. (2000). Gel formation in heat-treated bovine serum albumin-[kappa]-carrageenan systems. Food Hydrocolloids, 14(2), 95-110.

Olsson, C., Langton, M., \& Hermansson, A. M. (2002). Dynamic measurements of beta-lactoglobulin structures during aggregation, gel formation and gel breakup in mixed biopolymer systems. Food Hydrocolloids, 16(5), 477-488.

Otte, J., Lomholt, S. B., Ipsen, R., \& Qvist, K. B. (2000). Effect of partial hydrolysis with an immobilized proteinase on thermal gelation properties of beta-lactoglobulin B. Journal of Dairy Research, 67(4), 597-608.

Ould Eleya, M. M., Ko, S., \& Gunasekaran, S. (2004). Scaling and fractal analysis of viscoelastic properties of heat-induced protein gels. Food Hydrocolloids, 18(2), 315-323.
Paulsson, M., Dejmek, P., \& Vanvliet, T. (1990). Rheological properties of heatinduced beta-lactoglobulin gels. Journal of Dairy Science, 73(1), 45-53.

Pinterits, A., \& Arntfield, S. D. (2007). The effect of limited proteolysis on canola protein gelation. Food Chemistry, 102(4), 1337-1343.

Pollard, M. A., \& Fischer, P. (2006). Partial aqueous solubility of low-galactosecontent galactomannans - what is the quantitative basis? Current Opinion in Colloid E Interface Science, 11(2-3), 184-190.

Pouzot, M., Nicolai, T., Benyahia, L., \& Durand, D. (2006). Strain hardening and fracture of heat-set fractal globular protein gels. Journal of Colloid and Interface Science, 293(2), 376-383.

Pouzot, M., Nicolai, T., Durand, D., \& Benyahia, L. (2004). Structure factor and elasticity of a heat-set globular protein gel. Macromolecules, 37(2), 614-620.

Ross-Murphy, S. B. (1995). Structure-property relationships in food biopolymer gels and solutions. Journal of Rheology, 39(6), 1451-1463.

Schmitt, C., Sanchez, C., Desobry-Banon, S., \& Hardy, J. (1998). Structure and technofunctional properties of protein-polysaccharide complexes: a review. Critical Reviews in Food Science and Nutrition, 38(8), 689-753.

da Silva, J. A. L., \& Gonçalves, M. P. (1990). Studies on a purification method for locust bean gum precipitation with isopropanol. Food Hydrocolloids, 4, 277-287.

Sittikijyothin, W., Sampaio, P., \& Gonçalves, M. P. (2007). Heat-induced gelation of [beta]-lactoglobulin at varying $\mathrm{pH}$ : effect of tara gum on the rheological and structural properties of the gels. Food Hydrocolloids, 21(7), 1046-1055.

Syrbe, A., Bauer, W. J., \& Klostermeyer, N. (1998). Polymer science concepts in dairy systems - an overview of milk protein and food hydrocolloid interaction. International Dairy Journal, 8(3), 179-193.

Syrbe, A., Fernandes, P. B., Dannenberg, F., Bauer, W., \& Klostermeyer, H. (1995). Whey protein + polysaccharide mixtures: polymer incompatibility and its application. In E. Dickinson, \& D. Lorient (Eds.), Food macromolecules and colloids (pp. 328-339). London: Royal Society of Chemistry.

Tavares, C., \& da Silva, J. A. L. (2003). Rheology of galactomannan-whey protein mixed systems. International Dairy Journal, 13(8), 699-706.

Tolstoguzov, V. (1992). The functional properties of food proteins. In G. O. Philips, P. A. Williams, \& D. J. Wedlock (Eds.), Gums and stabilizers for the food industry Vol. 6 (pp. 241-266). Oxford: IRL Press.

Totosaus, A., Montejano, J. G., Salazar, J. A., \& Guerrero, I. (2002). A review of physical and chemical protein-gel induction. International Journal of Food Science and Technology, 37(6), 589-601.

Turgeon, S. L., \& Beaulieu, M. (2001). Improvement and modification of whey protein gel texture using polysaccharides. Food Hydrocolloids, 15(4-6), 583-591. 